\title{
FAKTOR-FAKTOR YANG MEMPENGARUHI MOTIVASI BELAJAR MAHASISWA: STUDI KASUS PADA FAKULTAS EKONOMI UNIVERSITAS BUNDA MULIA
}

\author{
Arko Pujadi \\ Email: arkopujadi@yahoo.com
}

\section{Penulis}

Arko Pujadi adalah staf pengajar tidak tetap di Jurusan Manajemen, Universitas Bunda Mulia, Jakarta dan menjadi koordinator dalam bidang Matematika Bisnis.

\section{Abstrak}

Penelitian bertujuan mengetahui karakteristik motivasi belajar mahasiswa Fakultas Ekonomi Universitas Bunda Mulia, perbedaan motivasi belajar diantara mahasiswa yang berbeda gender, jurusan dan tahun angkatan, serta hubungan antara motivasi belajar mahasiswa dengan faktor intrinsik dalam dirinya dan faktor-faktor ekstrinsik (lingkungan belajarnya), seperti kualitas dosen, materi kuliah, metode perkuliahan, kondisi dan suasana ruang kuliah, dan fasilitas perpustakaan. Sampel penelitian dipilih dari mahasiswa Fakultas Ekonomi Universitas Bunda Mulia dengan pertamatama mengelompokkan mereka dalam jurusan Akuntansi dan Manajemen, kemudian dari tiap jurusan tersebut dipilih sampel secara berjenjang dari angkatan tahun 2003, 2004 dan 2005.

Data dan informasi yang dikumpulkan dari sampel penelitian kemudian dianalisis dengan menggunakan metode deskriptif untuk mengetahui karakteristik motivasi belajar mahasiswa, dan metode induktif untuk menguji hipotesis mengenai perbedaan motivasi belajar diantara mahasiswa yang berbeda gender, jurusan dan tahun angkatan, serta hipotesis mengenai hubungan motivasi belajar mahasiswa dengan faktor intrinsik dan faktor-faktor ekstrinsiknya. Hasil penelitian menunjukkan bahwa motivasi belajar mahasiswa Fakultas Ekonomi Universitas Bunda Mulia masih perlu ditingkatkan. Motivasi belajar tersebut sama (merata) diantara mahasiswa yang berbeda gender, jurusan dan tahun angkatan.

Sementara, dari hasil pengujian terhadap faktor-faktor yang diduga memiliki hubungan dengan motivasi belajar mahasiswa, empat diantaranya, yaitu faktor intrinsik dalam diri mahasiswa, kualitas dosen, bobot materi kuliah, dan metode perkuliahan, terbukti memiliki hubungan yang signifikan dengan motivasi belajar mahasiswa. Sedangkan hubungan motivasi belajar mahasiswa dengan dua faktor lainnya, yaitu kondisi dan suasana ruang kuliah dan fasilitas perpustakaan, ternyata 


\section{Kata Kunci}

Motivasi Belajar, Faktor Intrinsik, Faktor Ekstrinsik

\section{PENDAHULUAN}

Rendahnya motivasi belajar mahasiswa kerap dituding sebagai biang keladi dari rendahnya kualitas lulusan sebuah perguruan tinggi. Pada kebanyakan perguruan tinggi swasta, faktor ini bahkan menimbulkan persoalan dilematis, karena dengan rendahnya motivasi belajar, sebenarnya tidak mungkin mahasiswa dapat menguasai bahan pembelajaran dengan baik, namun harus diluluskan demi kelangsungan perguruan tinggi tersebut. Praktek seperti ini menjadi aman dan langgeng, karena secara tidak langsung didukung oleh kebanyakan mahasiswa yang tujuan utamanya dalam mengikuti pendidikan tinggi juga, hanya sekedar untuk memperoleh gelar kesarjanaan, dan bukan untuk menguasai ilmu pengetahuan. Sementara, banyak perguruan tinggi swasta yang salah kaprah dalam menerapkan konsep kepuasan pelanggan (customer satisfaction) dalam dunia pendidikan, sehingga memudahkan mahasiswa lulus dianggap sebagai memberikan kepuasan kepada pelanggannya (mahasiswa).

Masyarakat Indonesia diperkirakan akan semakin rasional, sehingga lulusan perguruan tinggi kelak tidak lagi dipandang dari gelar kesarjanaan yang disandangnya, melainkan dari isi kepalanya. Gelar kesarjanaan tidak lagi menjadi tujuan utama seseorang dalam mengikuti pendidikan tinggi, melainkan penguasaan ilmu pengetahuan. Akan terjadi seleksi alamiah dimana hanya orang-orang yang benar-benar ingin menguasai bidang ilmu tertentu saja, yang akan melanjutkan ke jenjang pendidikan tinggi. Sedangkan, orang-orang yang hanya berburu gelar kesarjanaan akan menjadi out of date. Pada kondisi itu, maka kinerja perguruan tinggi tidak lagi diukur dari kemampuan dalam menghasilkan sebanyak-banyaknya sarjana, melainkan dari kemampuan dalam menghasilkan sebanyak-banyaknya sarjana yang berkualitas, yang diukur dari penguasaan terhadap ilmu pengetahuan.

Dewasa ini, seiring dengan pertumbuhan jumlah perguruan tinggi yang pesat, maka tingkat persaingan di antara perguruan tinggi dalam memperebutkan calon mahasiswa, juga menjadi semakin ketat. Hanya tersedia satu jalan bagi perguruan tinggi yang ingin bertahan dalam persaingan tersebut, yaitu melalui kualitas lulusan yang dihasilkannya. Banyak contoh dimana lulusan perguruan tinggi tidak diterima bekerja pada suatu perusahaan, karena melalui proses penyeleksian terbukti bahwa gelar kesarjanaan yang dimilikinya tidak sebanding dengan isi kepalanya. Perguruan tinggi yang menghasilkan lulusan seperti ini sebenarnya hanya tinggal menunggu waktu saja untuk ditinggalkan calon mahasiswanya.

Di Universitas Bunda Mulia, aspek kualitas tampaknya sudah menjadi commitment para pendirinya sejak awal. Hal ini tampak misalnya dari ketersediaan fasilitas pembelajaran yang sangat memadai. Perguruan tinggi ini juga telah mencanangkan tahun ini sebagai tahun dimulainya pengembangan e-learning. Namun, semua itu bisa tidak berarti apa-apa bagi penciptaan sarjana yang berkualitas jika tidak dibarengi dengan upaya untuk meningkatkan motivasi belajar mahasiswanya. Tanpa motivasi belajar, mahasiswa akan tetap malas belajar meski 
fasilitas belajar di kampusnya sangat memadai. Padahal tanpa belajar, mahasiswa tidak mungkin dapat memahami atau menguasai bahan pembelajaran dengan baik, sehingga kelak tidak mungkin menjadi sarjana yang berkualitas.

Dapat dikatakan bahwa motivasi belajar mahasiswa merupakan faktor yang paling menentukan dalam menciptakan sarjana yang berkualitas. Sehingga, sejalan dengan tekad Universitas Bunda Mulia untuk menghasilkan sarjana yang berkualitas, tekad itu kiranya dibarengi dengan upaya untuk meningkatkan motivasi belajar mahasiswanya. Penelitian ini bermaksud mencari tahu faktor-faktor yang mempengaruhi motivasi belajar mahasiswa, sehingga darinya dapat diperoleh masukan untuk merumuskan kebijakan yang tepat untuk meningkatkannya.

\section{TEORI MOTIVASI}

Pemuasan kebutuhan merupakan tujuan dari motif yang menggerakkan perilaku seseorang. Pada Gambar 2.1, motivasi dapat dipandang sebagai suatu rantai reaksi yang dimulai dari adanya kebutuhan, kemudian timbul keinginan untuk memuaskannya (mencapai tujuan), sehingga menimbulkan ketegangan psikologis yang akan mengarahkan perilaku kepada tujuan (kepuasan). Barelson dan Steiner dalam Koontz (2001: 115) misalnya, mendefinisikan motivasi sebagai suatu keadaan dalam diri seseorang (innerstate) yang mendorong, mengaktifkan atau meggerakkan, dan yang mengarahkan atau menyalurkan perilaku ke arah tujuan. Sementara menurut Luthans (2002:161), motivation is a process that starts with a pshycological deficiency or need a drive that is aimed at a goal or incentive.

Gambar 1.1.

Rantai motivasi

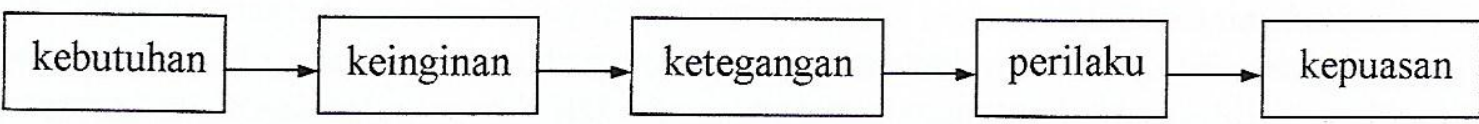

Sumber: Barelson dan Steiner dalam Koontz (2001: 115)

Teori hirarki kebutuhan (hierarchy of needs) yang dikembangkan Maslow (1954) memandang kebutuhan manusia berjenjang dari yang paling rendah hingga paling tinggi, dimana jika suatu tingkat kebutuhan telah terpenuhi, maka kebutuhan tersebut tidak lagi berfungsi sebagai motivator. Hirarki kebutuhan Maslow adalah sebagai berikut:

1. Kebutuhan fisik dan biologis (physiological needs), yaitu kebutuhan untuk menunjang kehidupan manusia seperti makanan, air, pakaian, dan tempat tinggal. Menurut Maslow, jika kebutuhan fisiologis belum terpenuhi, maka kebutuhan lain tidak akan memotivasi manusia.

2. Kebutuhan akan keselamatan dan keamanan (safety and security needs), yaitu kebutuhan untuk terbebas dari bahaya fisik dan rasa takut kehilangan.

3. Kebutuhan sosial (affiliation or acceptance needs), yaitu kebutuhan untuk bergaul dengan orang lain dan untuk diterima sebagai bagian dari yang lain.

4. Kebutuhan akan penghargaan (esteem or status needs), yaitu kebutuhan untuk dihargai oleh orang lain. Kebutuhan ini akan menghasilkan kepuasan seperti kuasa, prestis, status dan kebanggaan akan diri sendiri. 
5. Kebutuhan akan aktualisasi diri (self actualization needs), yaitu kebutuhan untuk mengaktualisasikan semua kemampuan dan potensi yang dimiliki hingga menjadi orang seperti yang dicita-citakan. Menurut Maslow, kebutuhan akan aktualisasi diri merupakan kebutuhan paling tinggi dalam hirarki kebutuhan.

Belakangan, Herzberg (1959) menyebut tiga kebutuhan terendah dalam hirarki kebutuhan Maslow, yaitu kebutuhan fisiologis, kebutuhan keamanan, dan kebutuhan sosial, sebagai faktor ketidakpuasan (dissatisfaction), artinya pemenuhan kebutuhan-kebutuhan tersebut hanya akan menghindarkan seseorang dari ketidakpuasan, namun tidak menghasilkan kepuasan. Sementara dua kebutuhan lainnya, yaitu kebutuhan akan penghargaan dan aktualisasi diri, disebut sebagai faktor kepuasan (satisfaction) yang akan menghasilkan perasaan puas atau tidak puas (no satisfaction), jadi bukan ketidakpuasan. Faktor yang pertama selanjutnya disebut sebagai faktor pemeliharaan (hygiene factors) sedangkan yang kedua disebut faktor motivasi (motivational factors). Dari sudut pandang lain, faktor pemeliharaan dapat juga disebut sebagai faktor intrinsik yaitu faktor dalam diri manusia, berupa sikap, kepribadian, pendidikan, pegalaman, pengetahuan dan cita-cita. Sedangkan faktor motivasi dapat disebut sebagai faktor ekstrinsik yaitu faktor dari luar diri manusia, berupa kepemimpinan, dorongan atau bimbingan, dan kondisi lingkungan.

Dalam pendekatan sistem, Lewin (1939) mengatakan bahwa perilaku manusia (behavior) merupakan fungsi dari manusianya sendiri (person) dan lingkungannya (environment). Fungsinya dapat ditulis sebagai berikut:

$$
B=f(P, E)
$$

dimana:

$\mathrm{B}=$ perilaku manusia (behavior)

$\mathrm{P}=$ manusia (person)

$\mathrm{E}=$ lingkungan (environment)

Jika pendekatan Lewin ini dikombinasikan dengan teori Herzberg, maka dapat dikatakan bahwa perilaku manusia dipengaruhi oleh faktor manusia, yaitu faktor dalam diri orang tersebut (intrinsik) dan faktor lingkungan yaitu faktor dari luar diri orang tersebut (ekstrinsik).

\section{MOTIVASI BELAJAR}

Dengan meminjam berbagai definisi tentang motivasi, maka motivasi belajar mahasiswa dapat didefinisikan sebagai suatu keadaan dalam diri mahasiswa yang mendorong dan mengarahkan perilakunya kepada tujuan yang ingin dicapainya dalam mengikuti pendidikan tinggi. Idealnya, tujuan mahasiswa dalam mengikuti pendidikan tinggi adalah untuk menguasai bidang ilmu yang dipelajarinya. Sehingga dalam mempelajari setiap bahan pembelajaran, mahasiswa terdorong untuk menguasai bahan pembelajaran tersebut dengan baik, dan bukan hanya untuk sekedar lulus meski dengan nilai sangat baik sekalipun. Meski secara konseptual tidak ada perbedaan antara meguasai bahan pembelajaran dengan baik dengan mendapat nilai baik untuk bahan pembelajaran tersebut, namun dalam dunia pendidikan tinggi swasta di Indonesia dewasa ini, seorang mahasiswa yang lulus dalam suatu bahan pembelajaran dengan nilai baik, belum tentu menguasai bahan pembelajaran tersebut dengan baik. Sebaliknya, jika seorang mahasiswa mampu menguasai suatu bahan 
pembelajaran dengan baik, maka hampir dapat dipastikan bahwa ia akan lulus dalam bahan pembelajaran tersebut dengan nilai baik pula. Semuanya ini dapat terjadi, karena metode evaluasi yang ada tampaknya belum bisa menghasilkan ukuran yang objektif terhadap penguasaan seorang mahasiswa dalam suatu bahan pembelajaran.

Untuk mencapai tujuan ideal tersebut, kebutuhan mahasiswa dalam konteks pendidikannya perlu ditingkatkan dari hanya sebagai kebutuhan akan penghargaan meminjam hirarki kebutuhan Maslow, - menjadi kebutuhan akan aktualisasi diri. Jika pendidikan tinggi dianggap hanya sebagai kebutuhan akan penghargaan, maka gelar kesarjanaanlah dan bukan penguasaan ilmu yang akan menjadi tujuan utama mahasiswa dalam mengikuti pendidikan tinggi. Sehingga ketika dalam kenyataannya, tujuan itu bisa dicapai tanpa harus susah payah belajar, buat apa pula belajar. Kelak di akhir proses pendidikannya, mahasiswa sudah merasa puas bisa menyandang gelar kesarjanaan di belakang namanya dan dengan demikian membuatnya bangga. Sebaliknya, jika pendidikan tinggi dianggap sebagai kebutuhan akan aktualisasi diri, maka mahasiswa akan mengeluarkan semua kemampuan dan potensi yang dimilikinya untuk memahami setiap bahan pembelajaran dengan baik. Pada tahap ini, belajar akan menjadi kegemaran yang mengasyikan karena adanya keiinginan atau semangat yang kuat untuk memahami bahan pembelajaran. Kelak di akhir proses pendidikan, ia akan puas dan merasa pantas menyadang gelar kesarjanaan karena merasa sudah memahami atau menguasai ilmunya.

Seperti dikatakan Herzberg, kedua tingkat kebutuhan tersebut, yaitu kebutuhan akan penghargaan dan aktualisasi diri, merupakan faktor motivasi yang bersumber dari dalam diri seseorang (intrinsik). Dengan demikian upaya untuk mengangkat kebutuhan pendidikan tinggi dari hanya sebagai kebutuhan akan penghargaan menjadi kebutuhan akan aktualisasi diri, harus dilakukan dari dalam diri mahasiswa. Instrumen dalam perguruan tinggi yang tepat untuk menjalankan tugas ini adalah penasehat akademik yang biasanya dijabat oleh seorang dosen. Penasehat akademik perlu memberi pemahaman kepada mahasiswa bahwa pendidikan tinggi merupakan kesempatan yang baik bagi mahasiswa untuk menampilkan semua kemampuan dan potensi yang dimilikinya. Keberadaan penasehat akademik sangat penting karena ia satu-satunya instrumen dalam perguruan tinggi yang bekerja dari dalam untuk memompa motivasi belajar mahasiswa, sementara instrumen lainnya bekerja dari luar (ekstrinsik).

Selanjutnya, dengan mengadopsi pendekatan sistem Lewin, motivasi belajar mahasiswa dapat dikatakan sebagai fungsi dari faktor yang ada dalam dirinya sendiri (intrinsik) dan faktor-faktor yang ada di dalam lingkungan belajarnya atau di luar dirinya (ekstrinsik). Faktor yang ada dalam diri mahasiswa adalah minatnya terhadap bidang ilmu yang dipelajari serta orientasinya dalam mengikuti pendidikan tinggi. Sedangkan faktor-faktor yang ada di dalam lingkungan belajarnya adalah kualitas dosen, bobot materi kuliah, metode perkuliahan, kondisi dan suasana ruang kuliah, serta fasilitas perpustakaan. Dengan demikian, fungsi motivasi belajar mahasiswa dapat ditulis sebagai berikut:

$$
\begin{aligned}
& y=f\left(x_{1}, x_{2}, x_{3}, x_{4}, x_{5}, x_{6}\right) \\
& \text { dimana: } \\
& y=\text { motivasi belajar mahasiswa } \\
& x_{1}=\text { faktor dalam diri mahasiswa (intrinsik) }
\end{aligned}
$$




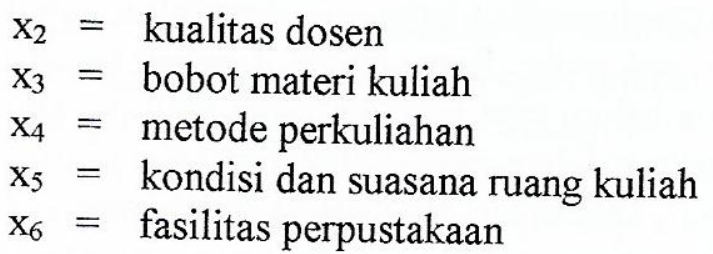

\section{KERANGKA BERPIKIR}

Berdasarkan tinjauan pustaka yang telah dipaparkan pada bagian di atas, selanjutnya dapat disusun kerangka berpikir dari penelitian ini, sebagai berikut:

Gambar 1.2.

Kerangka Berpikir

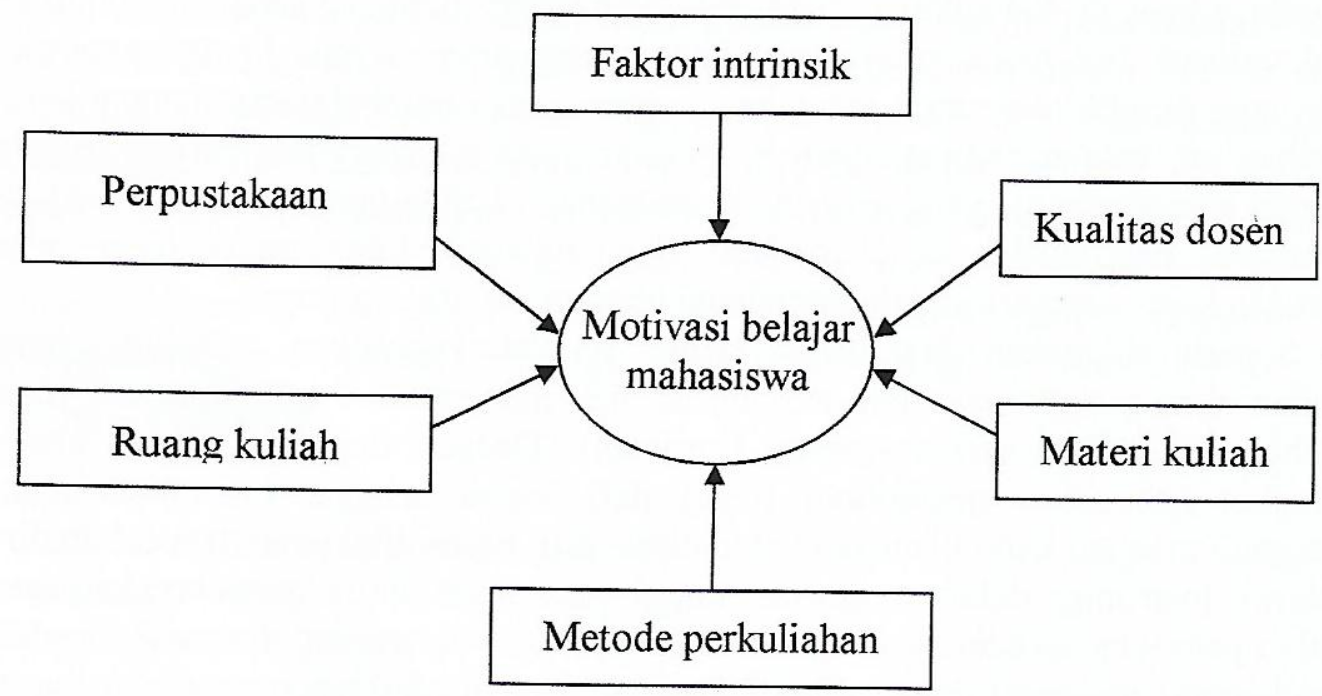

Penelitian ini membahas hubungan antara motivasi belajar mahasiswa sebagai variabel yang dipengaruhi (dependent variabel) dengan faktor intrinsik dalam diri mahasiswa, serta faktor-faktor ekstrinsik seperti kualitas dosen yang mengajar, materi kuliah, metode perkuliahan, ruang kuliah, dan perpustakaan, sebagai variabel bebasnya (independent variable). Dalam penelitian ini, hubungan antara motivasi belajar mahasiswa dengan faktor intrinsik dan faktor-faktor ekstrinsik akan dibuktikan dengan menerapkan metode statistika. Disamping itu, penelitian juga akan membuktikan apakah terdapat perbedaan motivasi belajar diantara mahasiswa yang berbeda gender, jurusan dan tahun angkatan.

\section{HIPOTESA PENELITIAN}

Berdasarkan tinjauan pustaka dan kerangka berpikir di atas, penelitian ini selanjutnya mengajukan hipotesis sebagai berikut:

1. Terdapat perbedaan yang signifikan di antara motivasi belajar mahasiswa Fakultas Ekonomi Universitas Bunda Mulia yang berbeda gender, jurusan dan tahun angkatan. 
2. Terdapat hubungan yang signifikan antara motivasi belajar mahasiswa Fakultas Ekonomi Universitas Bunda Mulia dengan faktor intrinsik dan faktor-faktor ekstrinsiknya.

\section{METODOLOGI PENELITIAN}

Penelitian ini dilakukan di Fakultas Ekonomi Universitas Bunda Mulia, Jakarta, selama 6 (enam) bulan, terhitung mulai dari bulan Juli 2006 hingga dengan bulan Desember 2006. Sebagai instansi tempat kami mengabdi sebagai dosen dan tempat kami menimba ilmu, Fakultas Ekonomi Universitas Bunda Mulia dipilih sebagai tempat penelitian agar hasil penelitian ini menjadi bentuk sumbangsih kami terhadapnya.

Penelitian ini menghubungkan satu variabel terikat (dependent variable) dengan beberapa variabel bebas (independent variabel), sebagai berikut:

1. Variabel terikat, yaitu motivasi belajar mahasiswa Fakultas Ekonomi Universitas Bunda Mulia.

Variabel ini diukur dari informasi mengenai:
a. frekuensi kepemilikan buku wajib yang dianjurkan dosen (text book),
b. keseriusan dalam mengikuti perkuliahan,
c. frekuensi bertanya pada dosen,
d. kerajinan dalam mengerjakan tugas mandiri,
e. sikap dalam mengikuti perkuliahan, serta
f. tingkat kehadiran dalam kegiatan perkuliahan.

2. Variabel bebas, yaitu faktor-faktor yang diduga memiliki pengaruh terhadap motivasi belajar mahasiswa Fakultas Ekonomi Universitas Bunda Mulia. Variabel ini terdiri dari faktor intrinsik yang ada di dalam diri mahasiswa dan faktor ekstrinsik yang berada di luar dirinya.

Faktor intrinsiknya diukur dari informasi mengenai:

a. minat terhadap bidang ilmu yang dipelajari, serta

b. orientasinya dalam mengikuti pendidikan tinggi.

Sedangkan faktor ekstrinsiknya diukur dari informasi mengenai:

a. kualitas dosen yang mengajar,

b. bobota materi kuliah yang diajarkan,

c. metode perkuliahan yang digunakan dosen,

d. kondisi dan suasana ruang kuliah, serta

e. fasilitas perpustakaan yang dapat dimanfaatkan mahasiswa.

Populasi dari penelitian ini adalah seluruh mahasiswa Fakultas Ekonomi Universitas Bunda Mulia, baik yang berasal dari Jurusan Akuntansi maupun Jurusan Manajemen, serta masih aktif mengikuti kegiatan perkuliahan di Fakultas Ekonomi Universitas Bunda Mulia. Sedangkan sampelnya dipilih dengan pertama-tama mengelompokkan mereka dalam jurusan Akuntansi dan Manajemen, kemudian dari tiap jurusan tersebut dipilih sampel secara berjenjang dari angkatan tahun 2003, 2004 dan 2005.

Penetapan batas awal tahun angkatan 2003 dengan pertimbangan bahwa mahasiswa angkatan tahun ini masih aktif, sedangkan mahasiswa angkatan tahun sebelumnya dianggap tidak aktif sehingga dianggap tidak lagi mengalami kondisi terkini dari lingkungan belajar di Fakultas Ekonomi Universitas Bunda Mulia. 
Sementara, penetapan batas akhir angkatan tahun 2005 dengan pertimbangan bahwa mahasiswa tahun angkatan itu telah memiliki pengalaman yang cukup, sedangkan angkatan tahun sesudahnya dianggap belum cukup. Dengan kata lain, batas minimal pengalaman yang dianggap cukup adalah jika mahasiswa tersebut telah mengikuti pendidikan selama satu tahun, sedangkan batas maksimalnya pengalaman selama empat tahun.

Analisis data diarahkan untuk menghasilkan kesimpulan yang dapat menjawab permasalah dalam penelitian ini, meliputi:

1. Analisis deskriptif digunakan untuk mendeskripsikan karakteristik dari motivasi belajar mahasiswa Fakultas Ekonomi Universitas Bunda Mulia, serta mendeskripsikan faktor intrinsik dan faktor ekstrinsik yang diduga berhubungan dengannya. Analisis deskriptif dikembangkan dengan menggunakan tabulasi silang (crosstabulation).

2. Analisis induktif digunakan untuk menguji hipotesis penelitian, yaitu:

a. Hipotesis mengenai perbedaan motivasi belajar diantara mahasiswa Fakultas Ekonomi Universitas Bunda Mulia yang berbeda gender, jurusan dan tahun angkatan. Pengujian beda motivasi belajar berdasarkan gender dan jurusan, dilakukan dengan menggunakan uji Mann-Whitney karena hanya melibatkan dua sampel. Sedangkan pengujian beda motivasi belajar berdasarkan tahun angkatan yang melibatkan tiga sampel, dilakukan dengan menggunakan uji Kruskal-Wallis.

b. Hipotesis mengenai hubungan antara motivasi belajar mahasiswa Fakultas Ekonomi Universitas Bunda Mulia dengan faktor intrinsik dan faktor ekstrinsiknya. Untuk mengujinya akan digunakan analisis korelasi Spearman.

Kedua pengujian menggunakan metode statistika nonparametrik mengingat data penelitian diukur dalam skala ordinal.

\section{HASIL PENELITIAN}

Untuk mengetahui faktor-faktor yang mempengaruhi motivasi belajar mahasiswa Fakultas Ekonomi Universitas Bunda Mulia, penelitian ini menganalisis data dan informasi yang dikumpulkan dari sampel sebanyak 129 mahasiswa. Sampel tersebut terdiri dari 62 mahasiswa jurusan Akuntansi dan 67 mahasiswa jurusan Manajemen yang berasal dari angkatan tahun 2003, 2004 dan 2005.

Tabel 1.1.

Profil Responden Berdasarkan Jurusan dan Angkatan 
angkatan * jurusan Crosstabulation

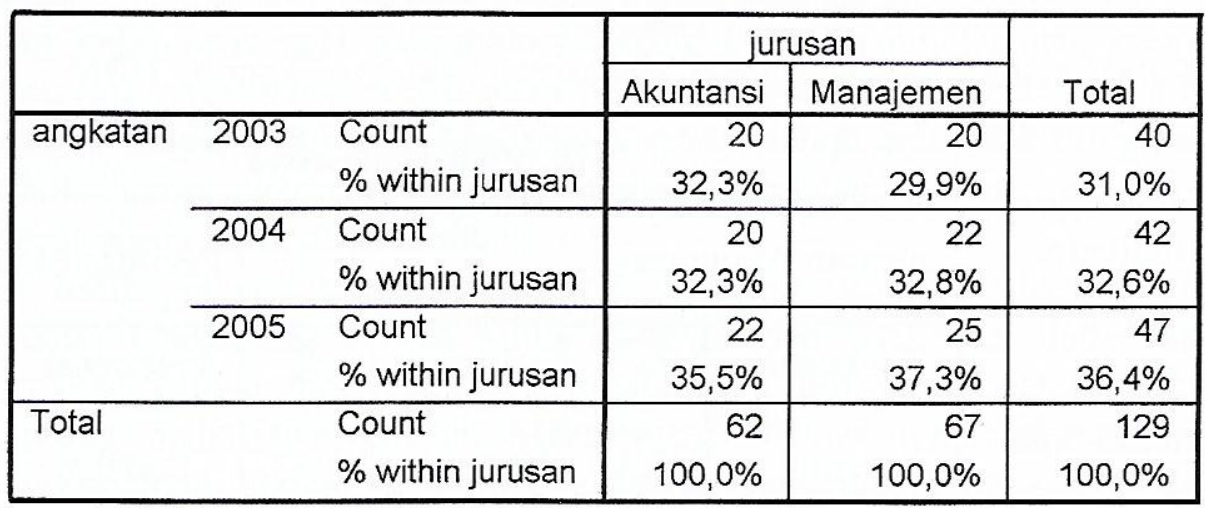

Sumber: Data Primer, 2006

Tabel 1.2.

Profil Responden Berdasarkan Jurusan dan Gender

gender * jurusan Crosstabulation

\begin{tabular}{|lll|r|r|r|}
\hline & & \multicolumn{2}{|c|}{ jurusan } & \multirow{2}{*}{} \\
\cline { 3 - 5 } & & Akuntansi & Manajemen & \multicolumn{1}{c|}{ Total } \\
\hline gender & laki-laki & Count & 27 & 40 & 67 \\
& & \% within jurusan & $43,5 \%$ & $59,7 \%$ & $51,9 \%$ \\
\cline { 2 - 5 } & perempuan & Count & 35 & 27 & 62 \\
& & \% within jurusan & $56,5 \%$ & $40,3 \%$ & $48,1 \%$ \\
\hline Total & & 62 & 67 & 129 \\
& & Count & $100,0 \%$ & $100,0 \%$ & $100,0 \%$ \\
\hline
\end{tabular}

Sumber: Data Primer, 2006

Motivasi belajar mahasiswa diindikasikan dari kepemilikan buku wajib yang dianjurkan dosen, keseriusan dalam mengikuti perkuliahan, frekuensi bertanya pada dosen, kerajinan dalam mengerjakan tugas mandiri, sikap dalam perkuliahan, serta tingkat kehadiran dalam kegiatan perkuliahan. Karakteristik motivasi belajar mahasiswa Fakultas Ekonomi Universitas Bunda Mulia dirangkum pada Tabel 4.3.

Berdasarkan tabel tersebut, motivasi belajar mahasiswa Fakultas Ekonomi Universitas Bunda Mulia tidak dapat dikatakan rendah, mengingat mereka masih memiliki tingkat keseriusan yang tinggi dalam mengikuti perkuliahan yang diberikan dosen serta rajin dalam mengerjakan tugas mandiri. Di samping itu, mahasiswa Fakultas Ekonomi Universitas Bunda Mulia jarang bolos kuliah, mengingat aturan akademik yang ketat yang melarang mereka mengikuti ujian jika tingkat kehadiran dalam perkuliahan kurang dari $75 \%$. Meskipun demikian, motivasi belajar tersebut juga tidak dapat dikatakan tinggi, mengingat mahasiswa hanya kadang-kadang memiliki buku wajib dan bertanya pada dosen. Demikian pula, mereka kadangkadang masih suka ngobrol dan berbuat berisik di dalam kelas pada saat perkuliahan sedang berlangsung. Dengan karakteristik seperti itu, maka dapatlah dikatakan bahwa motivasi belajar mahasiswa Fakultas Ekonomi Universitas Bunda Mulia tidak rendah tetapi juga tidak tinggi, atau bisa juga disebut kurang tinggi untuk menimbulkan konotasi bahwa motivasi belajar tersebut masih perlu ditingkatkan. 
Tabel 1.3.

Karakteristik Motivasi Belajar Mahasiswa Fakultas Ekonomi UBM

\begin{tabular}{|c|c|c|c|c|c|c|c|}
\hline \multirow{3}{*}{ No. } & \multirow{3}{*}{ Indikator } & \multicolumn{6}{|c|}{ Mayoritas mahasiswa } \\
\hline & & \multicolumn{2}{|c|}{ Jurusan Akuntansi } & \multicolumn{2}{|c|}{$\begin{array}{c}\text { Jurusan } \\
\text { Manajemen }\end{array}$} & \multicolumn{2}{|c|}{ Fakultas Ekonomi } \\
\hline & & Frekuensi & $\%$ & Frekuensi & $\%$ & Frekuensi & $\%$ \\
\hline 1. & $\begin{array}{l}\text { Memiliki buku } \\
\text { wajib }\end{array}$ & Sering & 40.3 & Kadang & 49.3 & Kadang & 38.8 \\
\hline 2. & $\begin{array}{l}\text { Menyimak } \\
\text { perkuliahan }\end{array}$ & Sering & 58.1 & Sering & 56.7 & Sering & 57.4 \\
\hline 3. & $\begin{array}{l}\text { Bertanya pada } \\
\text { dosen }\end{array}$ & Kadang & 37.1 & Kadang & 47.8 & Kadang & 42.6 \\
\hline 4. & $\begin{array}{l}\text { Mengerjakan } \\
\text { tugas mandiri }\end{array}$ & Sering & 59.7 & Sering & 58.2 & Sering & 58.9 \\
\hline 5. & $\begin{array}{l}\text { Ngobrol saat } \\
\text { kuliah }\end{array}$ & Jarang & 46.8 & Kadang & 49.3 & Kadang & 42.6 \\
\hline 6. & Bolos kuliah & Jarang & 69.4 & Jarang & 62.7 & Jarang & 65.9 \\
\hline
\end{tabular}

Sumber: Data Primer, 2006

Jika motivasi belajar mahasiswa Fakultas Ekonomi Universitas Bunda Mulia dibandingkan diantara jurusan Akuntansi dan Manajemen, maka dapat dikatakan bahwa motivasi belajar mahasiswa jurusan Akuntansi relatif lebih baik dibanding motivasi belajar mahasiswa jurusan Manajemen. Diantaranya, mahasiswa jurusan Akuntansi lebih sering memiliki buku wajib yang dianjurkan dosen dan lebih jarang ngobrol saat perkuliahan sedang berlangsung. Sementara, meski mahasiswa di kedua jurusan sama-sama sering menyimak perkuliahan dan mengerjakan tugas mandiri serta jarang bolos kuliah, namun proporsi mahasiswa yang melakukannya relatif lebih banyak di jurusan Akuntansi dibanding jurusan Manajemen.

\section{KESIMPULAN}

Berdasarkan hasil penelitian dan pembahasan yang dikembangkan pada bagian sebelumnya, diperoleh beberapa kesimpulan yang menjadi hasil dari penelitian ini, sebagai berikut:

1. Motivasi belajar mahasiswa Fakultas Ekonomi Universitas Bunda Mulia memiliki karakteristik dimana mereka pada umumnya masih memiliki tingkat keseriusan yang tinggi dalam menyimak perkuliahan yang diberikan dosen, serta rajin dalam mengerjakan tugas mandiri. Di samping itu, mereka juga jarang bolos kuliah meningat aturan akademik yang ketat yang melarang mereka mengikuti ujian jika tingkat kehadiran mereka dalam perkuliahan kurang dari $75 \%$. Namun, 
mereka hanya kadang-kadang memiliki buku wajib dan bertanya kepada dosen Demikian pula, mereka kadang-kadang masih suka ngobrol dan berbuat berisik di dalam kelas pada saat perkuliahan sedang berlangsung. Dengan karakteristik seperti itu, maka dapatlah dikatakan bahwa motivasi belajar mahasiswa Fakultas Ekonomi Universitas Bunda Mulia tidak rendah tetapi juga tidak tinggi, atau bisa disebut kurang tinggi untuk menimbulkan konotasi bahwa motivasi belajar tersebut masih perlu ditingkatkan.

2. Dari hasil perbandingan karakteristik motivasi belajar mahasiswa Fakultas Ekonomi Universitas Bunda Mulia pada jurusan Akuntansi dan Manajemen ditemukan bahwa motivasi belajar mahasiswa jurusan Akuntansi lebih baik dibanding mahasiswa jurusan Manajemen. Diantaranya, mahasiswa jurusan Akuntansi lebih sering memiliki buku wajib yang dianjurkan dosen, dan lebih jarang ngobrol pada saat kuliah, dibanding mahasiswa jurusan Manajemen. Sementara, meski mahasiswa di kedua jurusan tersebut sama-sama sering menyimak perkuliahan dan mengerjakan tugas mandiri serta jarang bolos kuliah, namun proporsi mahasiswa yang melakukannya relatif lebih banyak di jurusan Akuntansi dibanding jurusan Manajemen.

3. Dari hasil pengujian terhadap hipotesis penelitian yang menduga adanya perbedaan motivasi belajar diantara mahasiswa Fakultas Ekonomi Universitas Bunda Mulia yang berbeda gender, jurusan, dan tahun angkatan, terbukti bahwa perbedaan tersebut tidak signifikan dengan tingkat signifikansi 0,05. Dengan kata lain tingkat motivasi belajar mahasiswa Fakultas Ekonomi Universitas Bunda Mulia ternyata sama (merata), baik pada mahasiswa maupun mahasiswinya, pada jurusan Akuntansi maupun jurusan Manajemen, atau pada mahasiswa angkatan tahun 2003, angkatan tahun 2004 maupun angkatan tahun 2005.

4. Dari hasil pengujian terhadap hipotesis penelitian yang menduga adanya hubungan yang signifikan antara motivasi belajar mahasiswa Fakultas Ekonomi Universitas Bunda Mulia dengan faktor intrinsik serta faktor-faktor ekstrinsik dalam lingkungan belajarnya, empat variabel diantaranya yaitu faktor intrinsik, kualitas dosen, materi kuliah, dan metode perkuliahan, terbukti signifikan dengan tingkat signifikansi 0,01. Sedangkan hubungan motivasi belajar mahasiswa dengan dua variabel lainnya, yaitu ruang kuliah dan fasilitas perpustakaan, terbukti tidak signifikan dengan tingkat signifikansi 0,05. Selanjutnya jika koefisien korelasi keempat variabel yang signifikan tersebut dibandingkan, maka kualitas dosen memiliki hubungan yang paling kuat yaitu sebesar 0,373, dibanding variabel faktor intrinsik yang sebesar 0,286 , metode perkuliahan yang sebesar 0,259, atau materi kuliah yang sebesar 0,238

\section{DAFTAR PUSTAKA}

Gibson, James L., John M. Ivancevich dan James H. Donnely, Jr. 2002. Organisasi dan Manajemen: Perilaku, Struktur, Proses. Jakarta: Penerbit Erlangga.

Hageman, Gisela. 2000. Motivasi Untuk Pembinaan Organisasi. Jakarta: Pustaka
B 
Koontz, Harold, Cyril O'Donell dan Heinz Weihrich, Manajemen, Penerbit Erlangga, Jakarta, 2001.

Luthan, Fred., Organization Behavior, McGraw-Hill, New York, 2002.

Robbins, Stephen P., Organizational Behavior: Concept, Controversies and Application, Prentice Hall Inc., New Jersey, 1996.

Sardan. "Tantangan Perguruan Tinggi Swasta dalam Meghadapi Era Globalisasi dan Industrialisasi”. Widya, November 2002, hal. 45-50.

Schroeder, Roger G., Operation Management: Decision Making in the Operations Function, McGraw-Hill Book Co., Singapore, 2003.

Siegel, Sidney., Statistika Nonparametrik, Gramedia, Jakarta, 2004.

Sugiyono, Statistika untuk Penelitian, CV Alfabeta, Bandung, 2006. , Statistik Nonparameteris untuk Penelitian, CV Alfabeta, Bandung, 2006.

Suriasumatri, Jujun S., Filsafat Ilmu: Sebuah Pengantar Populer, Pustaka Sinar Harapan, Jakarta, 2005.

Suwarni, Sini., "Pendidikan Berorietasi Dunia Kerja dan Permasalahannya", Widya Oktober 2002, hal. 51-55

Wijaya, Statistika Non Parametrik: Aplikasi Program SPSS, CV Alfabeta, Bandung, 2000. 